\title{
TOWARD SUSTAINABLE RURAL ECOTOURISM EVOLUTION: THE CASE OF KISKAN, IRAN
}

\author{
Soroush Khalili' ${ }^{*}$, Pegah Moridsadat ${ }^{1}$, Hamid Soltaninejad' \\ 'Faculty of Earth Sciences, Shahid Beheshti University, Evin, 11369 Tehran, Iran. \\ *Corresponding author: s.khalili901@gmail.com \\ Received: October 21 th, 2019 / Accepted: May $10^{\text {th }}, 2020$ / Published: October 15t 2020 \\ https://DOI-10.24057/2071-9388-2019-133
}

\begin{abstract}
In Iran, due to the multiplicity, diversity and cultural-natural potential of rural areas, developing ecotourism is accepted as a key solution to sustainable rural development. The government putting strong emphasis on analysing the capacities and obstacles of promoting rural tourism in order to making effective strategies. Kiskan Rural District (KRD) in Kerman Province has great potential for ecotourism development to diversify rural economy, employment and income generation. So the purpose of this study is to investigate the rural ecotourism situation of KRD through SWOT analysis. It is an applied research that uses documentary and field methods including observation, unstructured interview and a questionnaire to data gathering. A group of local managers, counting Village Council Members and Rural Mayors, were selected by snowball sampling method. To this end, the status of rural ecotourism in KRD is determined and the weight of each of the four SWOT factors is measured. Results show that KRD ecotourism development strategy is «SO» (aggressive), which should exploit the strengths to take advantage of the available opportunities.
\end{abstract}

KEY WORDS: Ecotourism, Rural Development, SWOT, Kiskan, Kerman, Iran

CITATION: Soroush Khalili, Pegah Moridsadat, Hamid Soltaninejad (2020). Toward Sustainable Rural Ecotourism Evolution: The Case Of Kiskan, Iran. Geography, Environment, Sustainability.

https://DOl-10.24057/2071-9388-2019-133

Conflict of interests: The authors reported no potential conflict of interest.

\section{INTRODUCTION}

In many developing countries, a growing tourism industry is seen as a potential solution to issues such as low employment rates or the need for foreign currencies and generating higher government revenues (Rid et al. 2014). Moreover, the United Nations (UN) crafted the Sustainable Development Goals (SDGs) with tourism as among the driving forces that promote inclusive growth (Rivera and Gutierrez 2019). According to World Tourism Organisation, tourism can play a significant role in all seventeen goals of SDGs especially ending poverty (Goal 1) and hunger (Goal 2), promoting sustainable economic growth (Goal 8) and making human settlements more inclusive, safe, resilient and sustainable (Goal 11) (UNWTO 2015). Therefore, it is a fast growing industry (Lv 2019) around the world in many types such as ecotourism, geotourism, cultural, adventure, sport, and rural tourism, etc.

Ecotourism encompass both natural and socio-cultural aspects and sustainability is an integral condition of ecotourism (Price and Murphy 2000). The start point of the concept of sustainable tourism has been the Brundtland Commission Report (1987) which defined sustainable development. The World Tourism Organization designates sustainable tourism as «Tourism which fully takes into account its present and future economic situation, social and environmental impacts, addressing the needs of visitors, the industry, the environment and host communities» (Sörensson 2014). In this framework, ecotourism means responsible travel to natural areas, which seeks to conserve the environment and sustain the wellbeing of the local communities (Cobbinah et al. 2017). Since its creation in the 1980s, ecotourism has been widely discussed (Su et al. 2014). Recently, ecotourism has been confirmed as an impetus for sustainable economic and environmental development (Bhuiyan et al. 2016; Aliani et al. 2017; Amalu et al. 2018). According to researches, ecotourism brings numerous advantages, such as alleviate poverty, promoting socio-economic growth and well-being of local communities, natural resources conservation, and the economic and social improvement of nearby population (Su et al. 2014; Cater et al. 2015; Jozi and Moradi Majd 2015; Anup 2016; Chen and Qiu 2017).

Rural areas are one of the most meaningful parts of a territory, especially in developing countries, because of residential, economic, socio-cultural, productive, recreational and leisure functions, etc. A numerous of a country population, for example 25.9 percent of Iran's population, live in these area (Statistical Centre of Iran 2016). Because of the failure of classic strategies and policies, rural development is still facing many challenges, such as poverty, employment, food security and sustainable environment around the world including Iran (Haji Nejad et al. 2015). It has been identified that rural tourism is a key strategy to rural development (Greffe 1994; Kim and Jamal 2015; Gao and Wu 2017) or a policy to restructuring rural settlements or an instrument to sustainable development and natural resources conservation (Lane 1994; Slee et al. 1997; Roknoddin Eftekhari and Ghaderi 2002).

Rural tourism is a kind of tourism witch take place in rural area, so depending on the capacities, it includes all types of tourism, in particular ecotourism. Rural tourism is not a new phenomenon and grew in the nineteenth century in response to the fast urbanization to meet the 
leisure and recreation needs of urban dwellers (Lane 1994). In this way, for over a hundred years in certain parts of Europe, rural tourism has been recognized as an effective catalyst for rural socio-economic regeneration (Su 2011). It is noteworthy that, according to some sources, $10-20 \%$ of tourism income in EU countries falls to rural tourism (Paresishvili et al. 2017). Rural tourism can make full use of tourism resources in rural areas to adapt and optimize rural industrial structures, expand the agricultural industrial chain, flourish services for rural tourism, promote employment in non-agricultural jobs, increase the revenue of farmers, and setting up a better economic basis for the new rural construction (Zhang 2012).

Iran is a vast country with 31 provinces, 434 counties, 1319 cities, 2601 rural districts (Statistical Centre of Iran 2019) and about 60000 villages (Presidential Office 2015). This country has a wide range of socio-cultural and natural tourism attractions such as ethnic, racial (Fars, Turk, Lor, Kurd, Baluch, Arab, etc.) and religious (Muslim, Zoroastrianism, Christian, Jewish, etc.) diversity, more than 2500-year cultural heritage (Persepolis, Chogha-Zanbil Ziggurat, Ecbatana, etc.), historical mosques and houses (Jameh and Shah mosques in Isfahan, Tabatabaii house in Kashan, etc.), seas (Caspian sea, Persian Gulf and Oman Sea) and coastal areas, high mountains (Damavand, Alvand, Sabalan, etc.), caves (Alisadr, Kataleh Khor, Khoffash?, etc.), temperate northern forests with high humidity and rainfall $(1700 \mathrm{~mm})$, central deserts and salt lakes, glaciers, and etc. (Ghorbani et al. 2015). Economic development and increasing GDP besides exiting the oil-based singleproduct economy and entrepreneurship and job creation is the most important challenges of the country. So, tourism has recently been accepted by the government as a strategic solution. Therefore, investigating and analyzing the situation of the country and its subdivided, especially rural area, emphasized and some studies have been conducted on rural tourism in Iran by SWOT analysis (Feyzollahi 2004; Khatoonabadi and Rastghalam 2011; Ganjali et al. 2014; Karami and Sharifi 2014; Haji Nejad 2015; Eshraghi Samani et al. 2016; Kazemiyeh et al. 2016; Khougar et al. 2016).

Kerman, as the largest province of Iran, located in southeast of the country. Its heights are the continuation of the central mountain range of Iran that they begin from the volcanic folds of Azerbaijan and extend to Baluchistan and Central Desert (Dasht-e-Kavir) of Iran. Due to the geographical location, it has a considerable variety of climates, ranging from dry climate in the north, northwest, and central areas to warm and humid climate in the south and southeast (Iran Meteorological Organization 2019). This province has a significant situation in Iran's tourism industry with more than 91 natural and historical attractions and 41 tourism areas that scattered throughout this province (Jalali and Khademolhoseini 2015). Also, because of the long-running culture and history, it has a great potential to attract tourists from within and outside of Iran (Mehrabi Boshrabadi et al. 2011; Alipour et al. 2018; Najmi et al. 2018). Kiskan rural district (KRD) in Kerman has a vast range of ecotourism attractions such as mountain, rivers, springs and waterfalls, mild climate and clean air, calm environment, walnut trees and walnut harvest festival, traditional foods and confectionaries, and hand crafts, etc. Although some studies have been done on Kerman tourism issue (Tavallai 2006; Taboli and Yadollahi 2011; Bakhtiari and Bakhtiari 2013; Shafaei et al. 2015; Jalali and Khademolhoseini 2015; Zare et al. 2018), KRD remains neglected despite its vast natural and cultural potentials. For example, Haji Nejad et al. (2015) formulated a strategic plan for tourism development in Delfard village, Kerman province. The results indicate that the strength points of this region are over the weaknesses and their top strategy is active government engagement to strengthen the presence of private sectors and NGOs. Karimpour Reihan and Sharifi Jahed (2018) have mentioned that strategic tourism measures in Shahdad Desert, Kerman province, generally include the conversion of resources into tourist attractions, development of the tourism market, development of tourism facilities, tourism services and equipments, tourism marketing activities program and development of tourism infrastructures. Therefore, it is necessary to carry out studies for achieving tourism development strategies in KRD based on its internal and external driving and deterrent factors. In accordance with the gap, the purpose of this study is analyzing strengths, weaknesses, opportunities and threats of ecotourism development of KRD and identifying the appropriate strategies to this goal.

\section{Objectives}

Derived from the gap that recognized the shortage of researches focused on KRD, objectives of this study are:

- Introducing the most significant cultural and natural tourism attractions in KRD;

- Identifying the internal factors including strengths and weaknesses of KRD for developing ecotourism;

- Identifying the external factors including opportunities and threats of KRD for developing ecotourism;

- Analysing strengths, weaknesses, opportunities, and threats of ecotourism development of KRD and identifying the appropriate strategies to this goal.

\section{STUDY AREA}

KRD is located in the Central District of Baft County of Kerman province, at the foothill of Shah Mountain, also on Kerman Road to Baft, 20 kilometres from Baft City and 120 kilometres southwest of Kerman City. KRD geographical coordinates are $56^{\circ} 37^{\prime}$ to $56^{\circ} 39^{\prime} \mathrm{E}$ and $29^{\circ} 21^{\prime}$ to $29^{\circ} 23^{\prime} \mathrm{N}$. It is one of Halil River's largest sources (Young Journalist Club 2016). KRD has 2,219 households and 6,682 inhabitants that they live in 74 villages (Table 1). Karin, Moghuyeh, and Khushkar are the most populous villages of KRD (Statistical Centre of Iran 2016).

KRD is mountainous and its climate is cold in winter and mild in summer; the existence of rivers and abundant springs has contributed to the region's greenery. Walnut trees play a significant role in the economy of this region as one of the largest walnut producer's area of Iran. Apricot, peach and cherry trees have been planted in this rural district over the past couple of years. As mentioned above, this area has a great potential to develop ecotourism because of the existence of the verity cultural and natural tourism attractions (Table 2).

\section{METHODS}

This is an applied research. Documentary and field study methods were used for data gathering. Primary data were collected by observation, unstructured interview and a questionnaire that it marked based on the information provided by interviews. The local managers including Village Council Members and Rural Mayors (entitled Dehyar in Iran), informed about the potentials of study area and the 


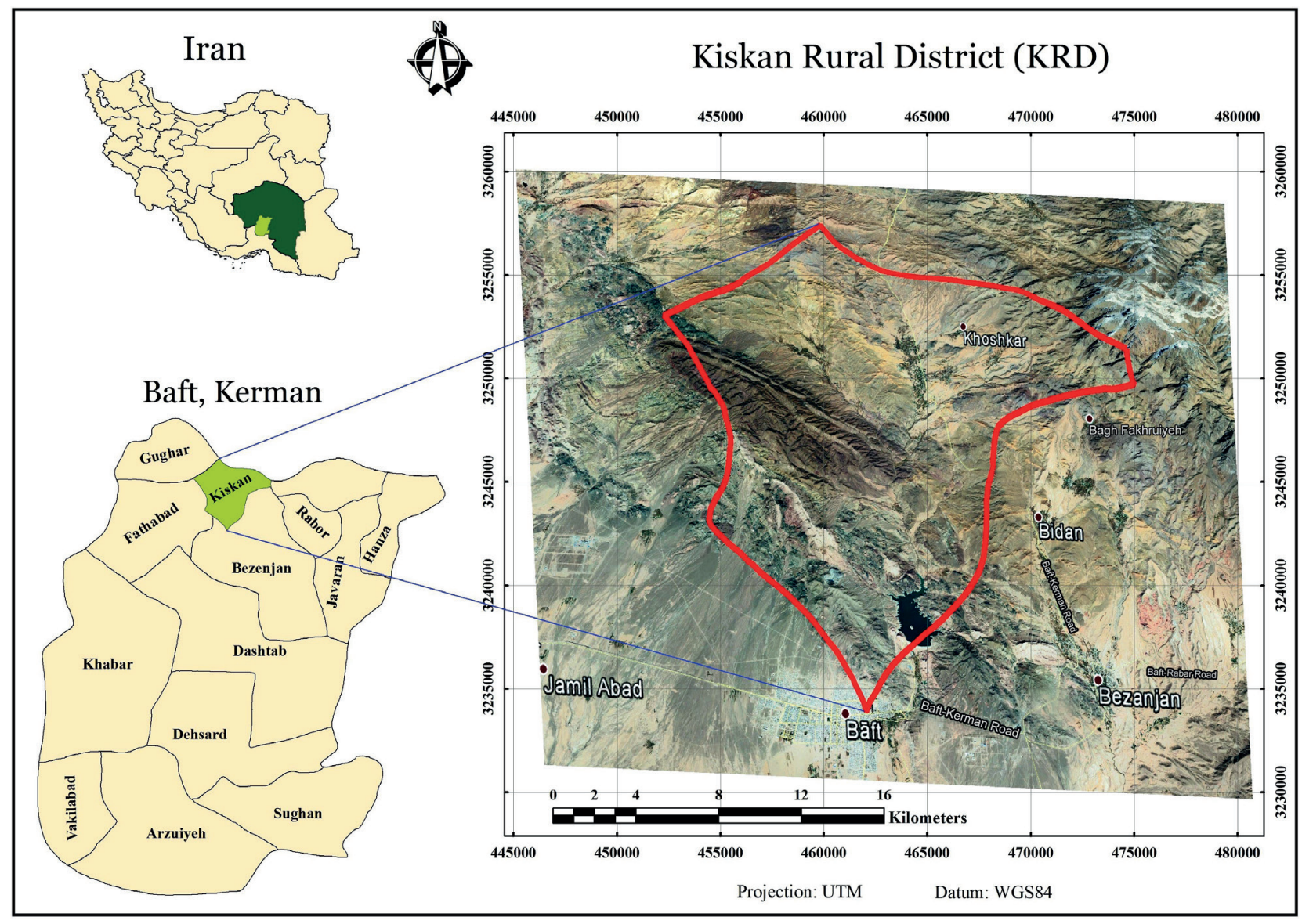

Fig. 1. The geographical location of the study area

Table 1. Demographic data of KRD (Statistical Centre of Iran 2016)

\begin{tabular}{|c|c|c|c|c|c|}
\hline \multirow{2}{*}{ County } & \multirow{2}{*}{ Sector } & \multirow{2}{*}{ Rural District } & \multicolumn{3}{|c|}{ Number of Villages } \\
\hline & & & Total & Inhabited & Uninhabited \\
\hline \multirow{6}{*}{ Baft } & \multirow{4}{*}{ Central } & Kiskan & 74 & 31 & 43 \\
\hline & & Bezenjan & 144 & 46 & 98 \\
\hline & & Fathabad & 124 & 38 & 86 \\
\hline & & Gogher & 185 & 53 & 132 \\
\hline & \multirow{2}{*}{ Khabar } & Khabar & 66 & 26 & 40 \\
\hline & & Dashtab & 141 & 29 & 112 \\
\hline
\end{tabular}

Table 2. Cultural and natural tourism attractions in KRD

\begin{tabular}{|c|c|}
\hline \multirow{8}{*}{ Natural } & Gardens, fields, pastures (walnut orchards, apricots, peaches) \\
\hline & Moderate mountain climate (cold winters and mild summers) \\
\hline & Abundant springs \\
\hline & «Sekase» waterfall in Jahanjan village \\
\hline & «Shah» mountain ranges (mountaineering and skiing( \\
\hline & «Meshkan» river \\
\hline & «Lanterns» valley \\
\hline & «Gonuiyeh» mountain village \\
\hline \multirow{6}{*}{ Cultural and Human } & Wedding ceremony (Hanging the flag) \\
\hline & Circumcision ceremony \\
\hline & Walnut festival \\
\hline & Different clans like «Lak» and «Turk» \\
\hline & High potential villages as tourism target (Jahanjan, Darremorid and Meshkan) \\
\hline & Hand crafts (carpet, kilim and pateh) \\
\hline
\end{tabular}




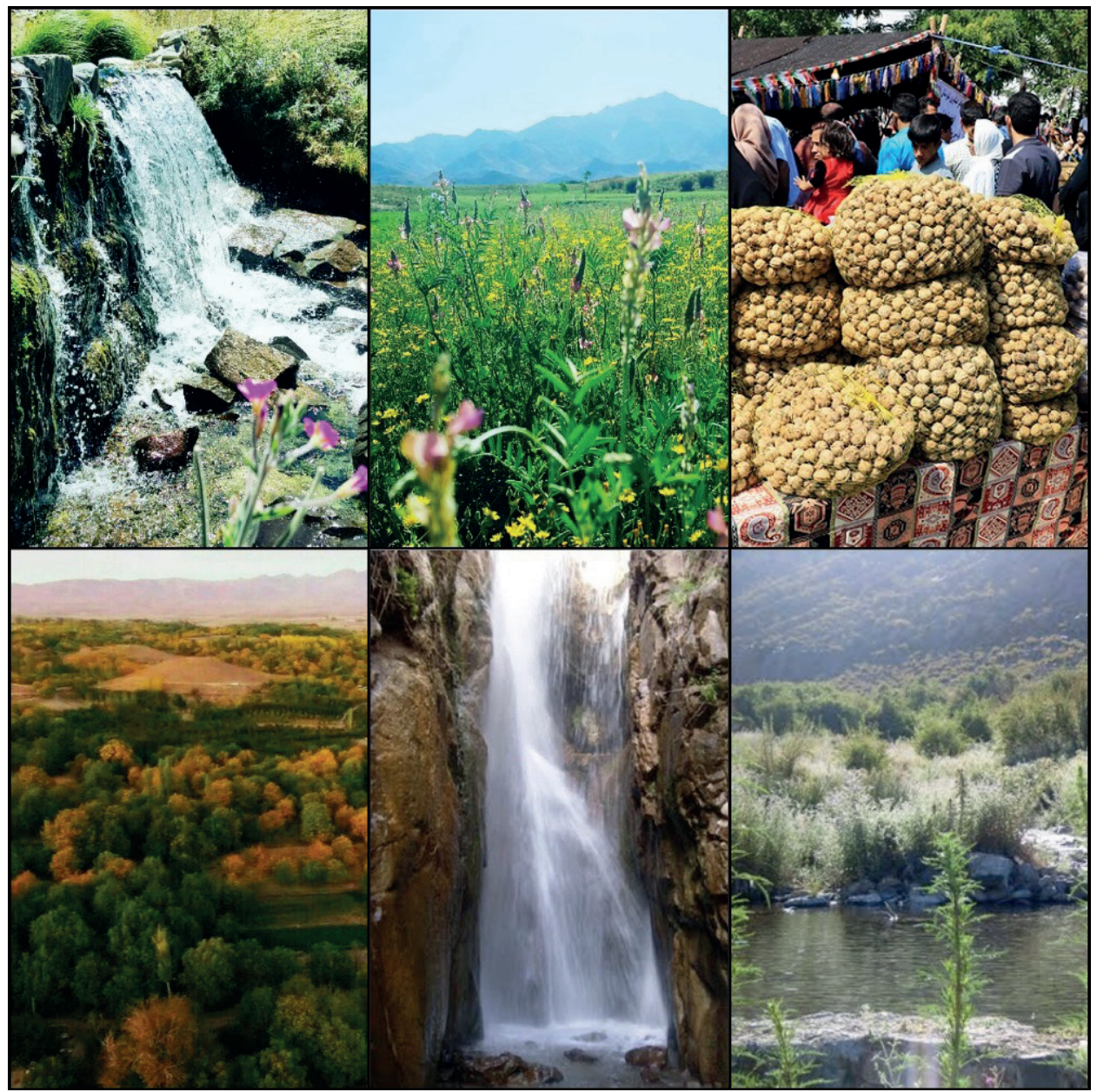

Fig. 2. Summary of ecotourism resources of the study area

rules and regulations of the country and its rural areas. 36 participants selected by snowball sampling method. Initially, local managers were interviewed about the strengths, weaknesses, opportunities and threats factors of the ecotourism development in the area. In compliance with these responses, a questionnaire consisting of the presented factors was prepared in four sections and the importance of each was determined by the respondents. Likert scale was used to elicit the opinions of participants about each factor. At last, SWOT analysis was used to analyze responses to the region's strengths, weaknesses, threats and opportunities and determine the best strategic situation. Furthermore, the required maps are drawn in the ArcGIS 10.6 software environment.

\section{SWOT analysis}

The origin of the SWOT analysis is moot. However, research has shown that the writings of Weihrich (1982); Dealtry (1992), and Wheelan and Hunger (1998) are credited as the beginning of the development of the methodology (Koch 2000). A SWOT analysis (also known as a SWOT matrix) is a structured planning method used to assess the strengths, weaknesses, opportunities and threats of a project (Shi 2016). It is a method to identify the potential strengths of an organization in order to exploit its opportunities to counter threats and dwindle weaknesses (Azubuike et al. 2018). Although SWOT analysis is a method of research commonly used in the field of business, a systematic evaluation of the decision and the policy directive has now been extended to natural resource management and also in the evaluation of sustainable tourism (Ghorbani et al. 2015).

The formation of a SWOT technique can only be explained by interacting with the formation of other strategic planning techniques, since before or simultaneously with the formation of this technique, other tools have been used to formulate the strategy (Golkar 2005). Concerning the Competitive Intelligent Foundation survey (Fehringer et al. 2006) which received answers from 520 competitive intelligent $(\mathrm{Cl})$ professionals, with $82.6 \%$ of respondents, SWOT is the second most commonly used analytical tool. SWOT analyses factors that are both helpful and harmful that originate from both internal and external of the organization or a strategic plan (Shi 2016). Strengths and Weaknesses are internal (controllable) factors that support and hinder organizations in achieving their mission respectively. Whereas Opportunities and Threats are the external (uncontrollable) factors that enable and disable organizations to fulfil their mission (Dyson 2004). It can be performed for a product, place, industry or person. It also includes the identification of internal and external factors which are favourable and unfavourable to achieving this objective (Ghorbani et al. 2015). The results are frequently presented as a matrix (Paschalidou et al. 2016).

There is no need to specify all the factors in SWOT analysis. Rather, those that are of paramount importance and can shape the future should be the focus of attention (Goranczewski and Puciato 2010). An important part of strategic planning is the scanning of internal and external environmental factors which is also regarded as a dominant component of the process of sustainable development. Such a strategic environment analysis is instrumental in formulating and selecting a strategy (Reihanian et al. 2012) as it can help researchers gain insight into the past and consider possible solutions to current or potential issues (Ommani 2011). The generation of alternative strategies is based on combining strengths and weaknesses (internal factors) with identified opportunities and threats (external factors). Four alternative strategic situations are then 
developed through Strategic Position \& Action Evaluation matrix (SPACE) as a logical continuation of SWOT matrix (Rehak and Grasseova 2011). They are «turnaround» (WO), «aggressive» (SO), «defensive» (WT), and «diversification» (ST) strategies that they mean (Feili et al. 2017):

- SO - «Strategies that use strengths to maximize opportunities»

- WO - «Strategies that minimize weaknesses by taking advantage of opportunities»,

- ST - «Strategies that use strengths to minimize threats», and

- WT - «Strategies that minimize weaknesses and avoid threats».

Finally, due to the strategic situation that is identified some strategic actions introduced. The main steps of the research process show in figure 3. The application of SWOT analysis enables the entities which are responsible for management of local or regional tourism policies in destinations, to position tourism in the overall and general strategic planning in a methodical and orderly way (Goranczewski and Puciato 2010).

\section{RESULTS}

After primary and secondary data collection about the ecotourism attractions in KRD and its driving factors and inhibitors that divided into two categories of external (opportunities and threats) and internal (strengths and weaknesses) factors, SWOT analysis was performed to specify the strategic priorities to ecotourism development in the area.

In conformity with the data gathered from local managers, 8 opportunities, 5 threats, 6 strengths and 10 weaknesses and their importance to ecotourism development in KRD were identified. We will continue to determine the weight of internal and external factors and calculate their final score in this rural district that affect the tourism industry, then will select the most appropriate strategic situation to realize this target. The results of these analyses are accordingly prepared in the following sections.

\section{External factor evaluation matrix (EFEM)}

In case of opportunities, 8 factors were recognized which have weights between 0.04 and 0.1 and effectiveness scores between 2 and 4. The final scores of the opportunities were between 0.08 and 0.4 . According to the results, «Increased tendency of returning immigration in the country», «The transportation system of the country and province (airport, railway, highway, rural road)», and «The existence of tourist attractions in the adjacent urban and rural areas (village of Sefteh, cave of Tarang, waterfall of Bongan, etc.)» had obtained the highest weight and final score (0.4). The next important factors respectively include «Proximity to the cities of Baft county (0.36)», «The existence of educated and job candidate youth in the country (0.32)» and «The country's policy on promoting the tourism industry (0.32)». Finally, «Internet access in the province» had the lowest weight and final score (0.18).

Moreover, there were 5 factors pertaining to threats that have obtained the weights between 0.04 and 0.1 and the final score between 0.4 and 0.08 . The highest weight (0.1) allocated to «The lack of hospitality and catering facilities along the road», and «The lack of government attention to advertising tourist places and the existence of an inconvenient advertising atmosphere in the province». According to these final scores «The lack of government

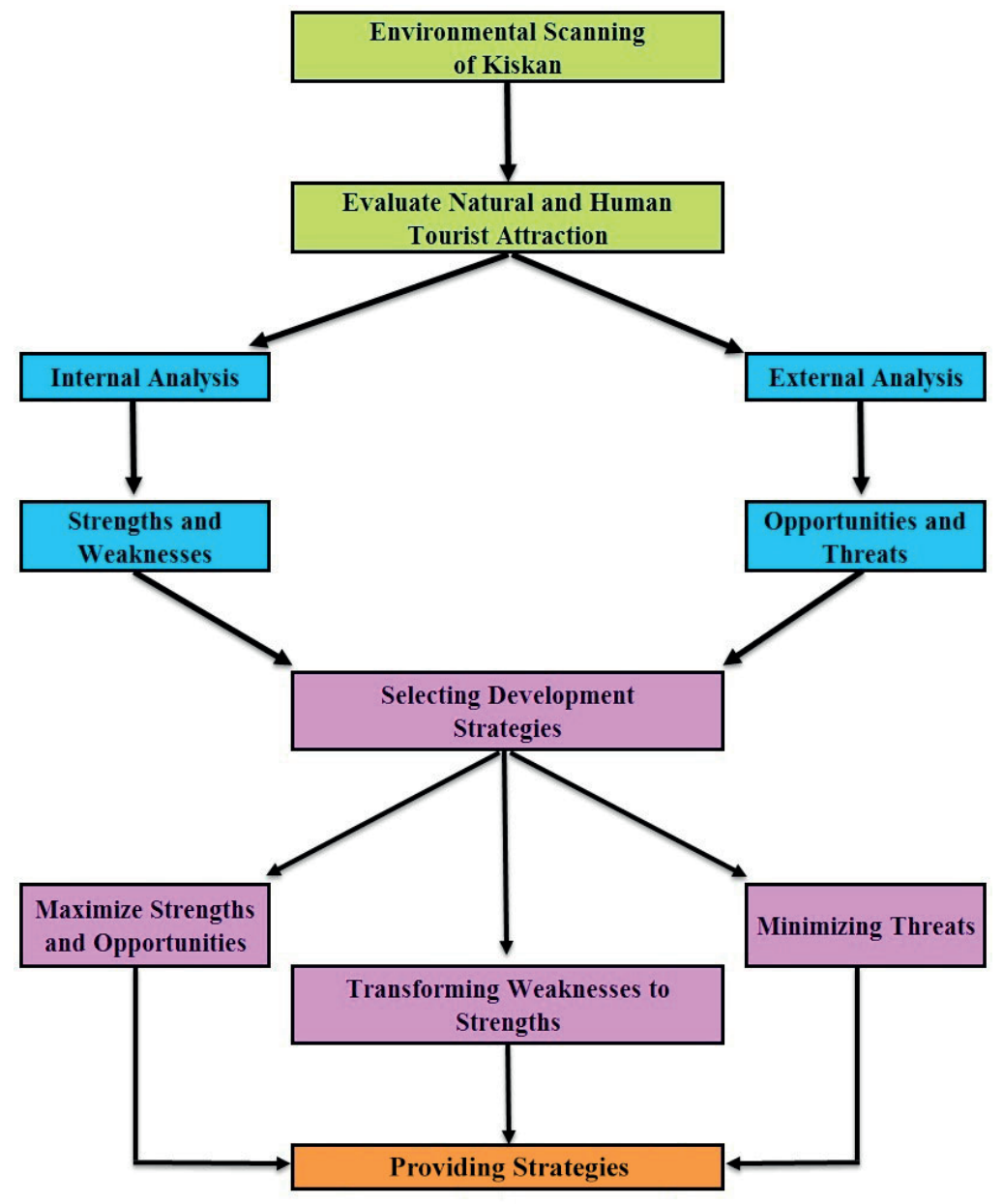

Fig. 3. Research process 
Table 3. External Factor Evaluation Matrix (EFEM)

\begin{tabular}{|c|c|c|c|}
\hline & Weight & Effectiveness score & Final score \\
\hline \multicolumn{4}{|l|}{ Opportunities } \\
\hline 1. Increased willingness among Iranians for «returning immigration» to their hometown & 0.1 & 4 & 0.4 \\
\hline 2. The relatively high safety of tourists in the country & 0.06 & 3 & 0.18 \\
\hline 3. The existence of educated and job candidates youth in the country & 0.08 & 4 & 0.32 \\
\hline 4. Proximity to the cities of Baft county (Baft and Bezanjan) & 0.09 & 4 & 0.36 \\
\hline $\begin{array}{l}\text { 5. The transportation system of the country and province (airport, railway, highway, } \\
\text { rural road) }\end{array}$ & 0.1 & 4 & 0.4 \\
\hline 6. Internet access in the province & 0.04 & 2 & 0.08 \\
\hline 7. The country's policy on promoting the tourism industry & 0.08 & 4 & 0.32 \\
\hline $\begin{array}{l}\text { 8. The existence of tourist attractions in adjacent urban and rural areas (village of } \\
\text { Sefteh, cave of Tarang, waterfall of Bongan, etc.) }\end{array}$ & 0.1 & 4 & 0.4 \\
\hline \multicolumn{4}{|l|}{ Threats } \\
\hline 1. The lack of hospitality and catering facilities on the roadside & 0.1 & 3 & 0.3 \\
\hline 2. Shortage of stopover, sanitary and hygiene facilities along the way in the country & 0.04 & 2 & 0.08 \\
\hline $\begin{array}{l}\text { 3. The lack of government attention to advertise tourist spots and existence of an } \\
\text { inconvenient advertising atmosphere in the province }\end{array}$ & 0.1 & 4 & 0.4 \\
\hline 4. Long cold season (decreased number of tourists during cold weather) & 0.07 & 3 & 0.21 \\
\hline 5. Low-interest public/private sector to invest in this industry & 0.04 & 2 & 0.08 \\
\hline Total & 1 & - & 3.53 \\
\hline
\end{tabular}

attention to advertising tourist spots ... (0.4)» has been the most important threat to ecotourism development in KRD and «The lack of hospitality ... (0.3)» situated in second priorities. Whereas the lowest final score $(0.08)$ is given to the «Shortage of stopover, sanitary and hygiene facilities along the way in the country», and «Low-interest public/ private sector to invest in this industry».

Ultimately, the total value of the external factor was 3.53; that is more than 2.5 which means that the opportunities overweight the threats. Table 3 summarizes the process and the outcome of external factor analysis.

\section{Internal factor evaluation matrix (IFEM)}

Regarding strengths and weaknesses, 6 and 10 factors were respectively selected and surveyed which have weights between 0.04-0.1 and effectiveness scores between 3 and 4 (for strengths), whereas for weaknesses they have weights between 0.02 and 0.1 and effectiveness scores between 1 and 4 .

According to the results, in case of strengths, the most important factors that obtained the highest weight (0.1) were identified to be «Favourable mountainous weather», «Human tourism attractions (ceremonies, celebrations, different clans, etc.)», and «Having quiet and calm environment for the rest of tourists». Their final score (0.4) also was more than the other factors. «Natural attractions and unique perspectives» of KRD such as Shah mountains, springs, rivers, waterfalls, and pastures as well as «The existence of diverse agricultural products» like walnuts, apricots and peaches were ranked second in terms of their weights (0.08) and final scores (0.32). At last between the strength factors «The location of the rural district on the Kerman-Baft road leads to the possibility of attracting passengers when crossing the road» obtained the least weight (0.04) and so on the final score (0.12). In other words, it is the least important factor than the other Strengths.

In case of weaknesses, the highest weight (0.1) and final score (0.4) belong to the following factor: «Inappropriate tourism infrastructure (accommodation, hospitality, public restroom) in the rural district». So it is the most significant weakness for developing ecotourism in the study area. After it, four factors get the highest weight (0.06) but according to their effectiveness scores and calculated the final scores, the factors including «Long cold season and reduced number of tourists during cold weather (0.24)», and then «The lack of recognition of residents with tourism benefits (0.18)», and «The destruction of traditional district by old residents (0.18)» situated in the second and third priorities of weakness. Among these «The lack of a plans and activities to attract tourists» get the same final score (0.12) with «The hardness of the local access to natural attractions due to the weakness of the transportation system» and «Low speed Internet in the rural area». In addition, «Natural attractions' long distance from each other» and «Cultural conflicts between tourists and indigenous people» obtained minimum weight (0.02) and the least final score respectively 0.04 and 0.02 .

Accordingly, the total value of internal factors (3.46) is more than 2.5 which means that the strengths overweight the weaknesses (Table 4).

\section{Developing strategies, space matrix}

Based on identifying the four factors of SWOT to improve opportunities and strengths, as well as eliminating weaknesses and threats, is inevitable in order to provide strategies for the evolution of ecotourism in the KRD. By using the sum of the score of internal and external factor that calculate above and entering them in SPACE matrix, the strategic situation to develop ecotourism in KRD is identified. As shown in Fig. 4, according to appropriate level of scores (more than 2.5 for both internal and external factors), the cross point of the total score of the factors is located in the "SO» area that highlighted. Therefore, the «SO» strategy or in other word «aggressive strategy» was determined as a suitable strategic position toward ecotourism development in KRD. 
Table 4. Internal Factor Evaluation Matrix (IFEM)

\begin{tabular}{|c|c|c|c|}
\hline & Weight & Effectiveness score & Final score \\
\hline \multicolumn{4}{|l|}{ Strengths } \\
\hline 1. Favourable mountain weather & 0.1 & 4 & 0.4 \\
\hline $\begin{array}{l}\text { 2. Natural attractions and unique perspectives (e.g. Shah mountains, springs, rivers, } \\
\text { waterfalls and pastures) }\end{array}$ & 0.08 & 4 & 0.32 \\
\hline 3. Human tourism attractions (ceremonies, festivals, celebrations, various clans, etc.) & 0.1 & 4 & 0.4 \\
\hline 4. The existence of diverse agricultural products (walnuts, apricots, peaches, etc.) & 0.08 & 4 & 0.32 \\
\hline 5. A quiet and calm environment for tourists & 0.1 & 4 & 0.4 \\
\hline $\begin{array}{l}\text { 6. The location of the rural district on the Kerman-Baft road leads to the possibility of } \\
\text { attracting passengers by crossing the road }\end{array}$ & 0.04 & 3 & 0.12 \\
\hline \multicolumn{4}{|l|}{ Weaknesses } \\
\hline $\begin{array}{l}\text { 1. The lack of local participation in decision-making and implementation for tourism } \\
\text { development planning }\end{array}$ & 0.04 & 2 & 0.08 \\
\hline $\begin{array}{l}\text { 2. Inappropriate tourism infrastructure (accommodation, hospitality, public restroom) } \\
\text { in rural district }\end{array}$ & 0.1 & 4 & 0.4 \\
\hline 3. The lack of recognition of residents with tourism benefits & 0.06 & 3 & 0.18 \\
\hline $\begin{array}{l}\text { 4. The hardness of the local access to natural attractions due to the weakness of the } \\
\text { transportation system in this area (e.g. waterfalls of Khushkar) }\end{array}$ & 0.04 & 3 & 0.12 \\
\hline 5. Natural attractions' long distance from each other & 0.02 & 2 & 0.04 \\
\hline 6. Low speed Internet in the rural area & 0.04 & 3 & 0.12 \\
\hline 7. The destruction of traditional district by old residents & 0.06 & 3 & 0.18 \\
\hline 8. The lack of a plans and activities to attract tourists in the area & 0.06 & 2 & 0.12 \\
\hline 9. Cultural conflicts between tourists and indigenous people & 0.02 & 1 & 0.02 \\
\hline 10. Long cold season and reduced number of tourists during cold weather & 0.06 & 4 & 0.24 \\
\hline Total & 1 & - & 3.46 \\
\hline
\end{tabular}

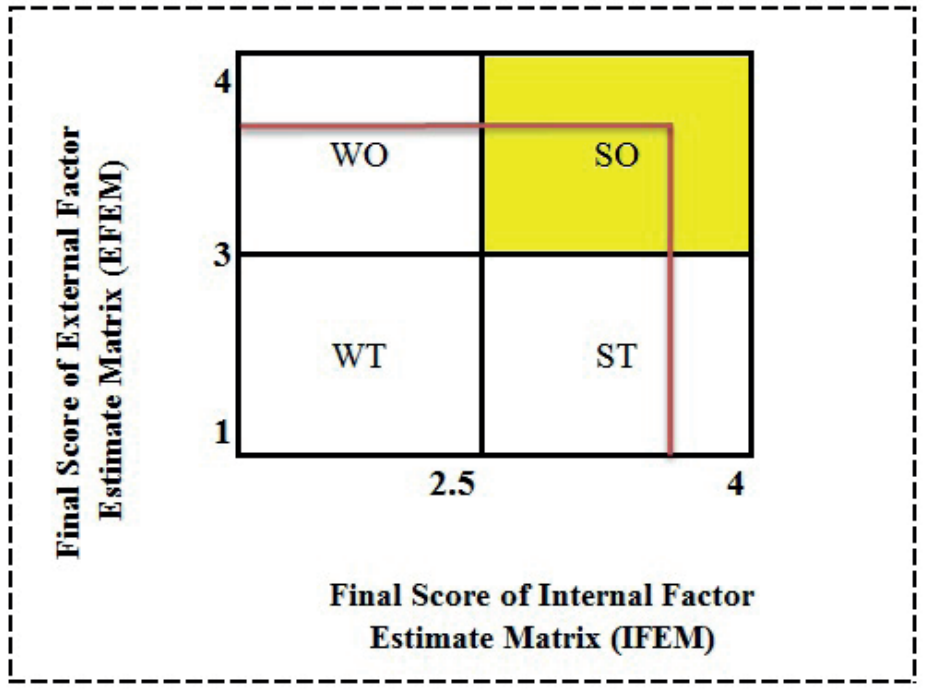

Fig. 4. Strategic Position \& Action Evaluation matrix of developing ecotourism in KRD

Accordant with the determined position (SO) to develop ecotourism in study area, making some strategies that use strengths to maximize opportunities is essential. It was done by a pair wise matching of recognised strengths and opportunities. The results show 3 strategies including:

(SO1): «Building up tourism packages in the area, to increase the interest of domestic and foreign tourists». This strategy proposed on the basis of the power of S1, $\mathrm{S} 2, \mathrm{~S} 3, \mathrm{~S} 4, \mathrm{~S} 5$ in order to exploit O3, O4, $\mathrm{O} 8$.
(SO2): «Introducing the tourism capacities of KRD from international to local level, by traditional and modern communication channels, especially ICTs». This is defined by utilization $\mathrm{S} 1, \mathrm{~S} 2, \mathrm{~S} 3, \mathrm{~S} 4, \mathrm{~S} 5$ to maximize the opportunities including $\mathrm{O} 1, \mathrm{O} 2, \mathrm{O} 6, \mathrm{O} 7, \mathrm{O} 8$.

(SO3): «Use the national and provincial transportation system to transfer tourists». It makes-up by maximizing the strength $\mathrm{S} 6$ to utilization opportunities $\mathrm{O} 2, \mathrm{O} 4, \mathrm{O} 5$. 


\section{DISCUSSION}

The province of Kerman as Iran's largest province ranks first in the country. Kerman has plenty fascinating historical attractions in its arms, making it one of the five historic cities in Iran. Regarding the antiquity of monuments, remains of the past are evidence that at least during the reign of King Ardashir 12, there was a city of great prosperity and strongholds. Fabulous architecture, a lot of local culture, Zoroastrian faith and fire temples, traditional handicrafts and beautiful landscape are some of the highlights this province offers to its visitors. As one of the tourism target villages in the province, Kiskan is a watershed of the Baft river with its high rivers and numerous springs. Another point is the customs of the people there. The culture of Kerman province has been influenced by the combination of urban, rural and nomadic communities as well as influenced by historical trends and religious rituals and these factors have led to the emergence of sub-cultures across the vast province of Kerman. In general, the culture of the Kerman region is based on two factors: natural conditions on the one hand and vicissitudinous history of this region on the other. Among the famous celebrations there is the «Sadeh» celebration, one of the oldest Iranian celebrations and it is still popular among Kerman people, especially Zoroastrians and has a lot of fans.

Ecotourism development in any region requires basic studies and comprehensive knowledge of natural, human resources, investment opportunities and other tourism capabilities and potentials. It is recognized as one of the most favourable forms of tourism industry, which is suitable for Iran. Many researches have been done to date on the role, disadvantages and benefits of tourism in Iranian villages. As in the present study, the findings of Mosavi et al. (2019) confirm that infrastructure investment leads to increased tourist visits to rural areas and the most necessary investment is in relation to the welfare and services variables. Riahy and Roshanali (2019) and Ahmadi (2018) surveys show that rural tourism development can play a substantial role in improving entrepreneurial conditions among local residents. Concerning KRD, we conclude that in order to provide the proper facilities in the villages, we need private and public sectors to invest in ecotourism. But, contrary to the results we obtained in our paper, Bahari (2018) showed that the presence of tourists in the Neyshabur area (in Mashhad province) could not contribute to the economic development of the villages. It has also mentioned that tourists have damaged the environment of the area and caused pollution. With regard to the development and promotion of educational and notification programs to local residents in the field of ecotourism as well as the marketing and advertising of ecotourism potentials (at local, national and transnational level), Salehpour et al. (2019) have been in agreement with our findings.

\section{CONCLUSION}

This study investigates the current situation and factors including strengths, weaknesses, opportunities and threats which affect ecotourism development in KRD by SWOT. Considering the cultural background and landscapes of $K R D$, this rural district is having one of the most significant ecotourism potentials in Kerman Province. Human and cultural tourism attractions in the area and its neighbours, favourable mountain weather, quiet and calm environment for tourists and accessible transportation system are the most important internal and external positive points to the end. Reversely, lack of tourism infrastructures and facilities and also, advertisement about the tourism industry in national and local level are the most powerful internal and external obstacles for ecotourism development in KRD. Based on the final score of these factors and their cross points in SPACE matrix, the development of ecotourism depends on adopting aggressive strategies. In this framework building up tourism packages, introducing the tourism capacities of the area and utilizing the existence transportation infrastructure is emphasized. Besides, it is necessary to act in order to overcome obstacles. So improving the tourism infrastructure such as hotel, ecotourism residence, resorts facility along the roads, local transportation and sanitation system are crucial. In addition, making effective policies to attract the private sector, entrepreneurs and local communities, aiming to promote investment to develop ecotourism in the area is vital. Accordingly, ecotourism should be on the agenda of the provincial planners and the required exploitations should be matched with the economic developments in the provincial villages.

\section{REFERENCES}

Ahmadi M. (2018). The Analysis of the Factors Affecting the Development of Cultural Tourism and its Effects on Economic Sustainability: A Case study on the Rural Areas of Zanjan Province. Regional Planning, 8(29), 79-92. [online] Available at: www.jzpm.miau.ac.ir/article_2776. html [Accessed 20 May 2020].

Aliani H., BabaieKafaky S., Saffari A. and Monavari S.M. (2017). Land evaluation for ecotourism development — an integrated approach based on FUZZY, WLC, and ANP methods. International Journal of Environmental Science and Technology, 14(9), 1999-2008, DOI: 10.1007/ s13762-017-1291-5.

Alipour A., Hashemi S.M., Khalifeh E. and Moradi A. (2018). Studying of the role of tourism in the social sustainable development of the sandy and salty regions, case study: Kerman Province. Management System, 7(28), 39-50. [online] Available at: www.jzpm.miau.ac.ir/ article_2530.html [Accessed 20 May 2020].

Amalu T.E., Otop O.O., Duluora E.I., Omeje V.U. and Emeana S.K. (2018). Socio-economic impacts of ecotourism attractions in Enugu state, Nigeria. GeoJournal, 83(6), 1257-1269, DOI: 10.1007/s10708-017-9830-7.

Anup K.C. (2016). Ecotourism and Its Role in Sustainable Development of Nepal. In L. Butowski, Tourism - From Empirical Research Towards Practical Application (1st ed.). InTech.

Bahari N. (2018). The Role of Tourism in Rural Economy (Case Study: Mianfazl Rural District of Neyshabur). Journal of Architecture, 1(2). [online] Available at: www.memarishenasi.ir/fa/archive.php?pid=113\&rid=2 [Accessed 20 May 2020].

Bakhtiari B. and Bakhtiari A. (2013). Determination of tourism climate index in Kerman province. DESERT, 18(2), 113-126. [online] Available at: www.jdesert.ut.ac.ir/article_50003.html [Accessed 20 May 2020].

${ }^{2}$ Ardashir I or Ardeshir l, also known as Ardashir the Unifier, was the founder of the Sasanian Empire. 
Bhuiyan M.H., Siwar C., and Ismail S.M. (2016). Sustainability Measurement for Ecotourism Destination in Malaysia: A Study on Lake Kenyir, Terengganu. Social Indicators Research, 128(3), 1029-1045, DOI: 10.1007/s11205-015-1068-5.

Cater C., Garrod B. and Low T. (2015). The Encyclopaedia of Sustainable Tourism. CABI.

Chen B. and Qiu Z. (2017). Community attitudes toward ecotourism development and environmental conservation in nature reserve: a case of Fujian Wuyishan National Nature Reserve, China. Journal of Mountain Science, 14(7), 1405-1418, DOI: 10.1007/s11629-016-3983-6.

Cobbinah P.B., Amenuvor D., Black R. and Peprah C. (2017). Ecotourism in the Kakum Conservation Area, Ghana: Local politics, practice and outcome. Journal of Outdoor Recreation and Tourism, 20, 33-44, DOI: 10.1016/j.jort.2017.09.003.

Eshraghi Samani R., Malekshahi S. and Poursaeed A. (2016). Development Strategies for Rural Tourism in Mishkhas Village. International Journal of Agricultural Management and Development, 257-264. [online] Available at: www.ijamad.iaurasht.ac.ir/article_523926.html [Accessed 20 May 2020].

Feyzollahi M.H. (2004). Rural Tourism Development Capabilities in Meshkinshahr County, Rural Districts of Western Meshkin and Eastern Meshkin. Shahid Beheshti University. Master Thesis for Rural Planning. [online] Available at: www.library.sbu.ac.ir/islandora/object/ thesis\%3A22719 [Accessed 20 May 2020].

Ganjali S., Shayesteh K., Ghasemi A., and Mohammadi H. (2014). Environmental and strategic assessment of ecotourism potential in Anzali Wetland using SWOT analysis. Caspian Journal of Environmental Sciences, 12(1), 155-165. [online] Available at: www.cjes.guilan.ac.ir/ article_1139.html [Accessed 20 May 2020].

Gao J. and Wu B. (2017). Revitalizing traditional villages through rural tourism: A case study of Yuanjia Village, Shaanxi Province, China. Tourism Management, 63, 223-233, DOI: 10.1016/j.tourman.2017.04.003.

Ghorbani A., Raufirad V., Rafiaani P. and Azadi H. (2015). Ecotourism sustainable development strategies using SWOT and QSPM model: A case study of Kaji Namakzar Wetland, South Khorasan Province, Iran. Tourism Management Perspectives, 16, 290-297, DOI: 10.1016/j. tmp.2015.09.005.

Golkar, K. (2005). Adaptation of SWOT Analytical Technique for Application in Urban Design. Soffeh, 15(41), 44-65. [online] Available at: www.sid.ir/fa/journal/ViewPaper.aspx?id=54029 [Accessed 20 May 2020].

Greffe X. (1994). Is rural tourism a lever for economic and social development? Journal of Sustainable Tourism, 2(1-2), 22-40, DOl: 10.1080/09669589409510681.

Haji Nejad A., Paydar A., Bagheri F., and Abdi N. (2015). Projection of the Strategic Planning of Iran Rural Rourism Development. The Macro and Strategic Policies, 2(8), 111-135. [online] Available at: www.jmsp.ir/article_7946.html [Accessed 20 May 2020].

Iran Meteorological Organization. (2019). The Climate of Kerman Province. [online] Available at: www.irimo.ir/far/services/climate/811-

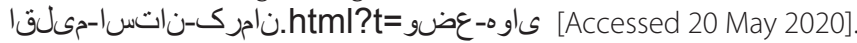

Jalali M. and Khademolhoseini A. (2015). The Classification of Tourism Sample Regions (Case Study: Kerman Province). Management System, 5(17), 151-162. [online] Available at: www.jzpm.miau.ac.ir/article_726.html [Accessed 20 May 2020].

Jozi S.A. and Moradi Majd N. (2015). Ecological Land Capability Evaluation of Dehloran County in Order to Ecotourism Development. Journal of the Indian Society of Remote Sensing, 43(3), 571-581, DOI: 10.1007/s12524-014-0427-z.

Karami F. and Sharifi R. (2014). Assessment of Rural Tourism through SWOT (Case Study: Rurals of Maragheh Central District). Geography and Planning, 17(46), 199-221. [online] Available at: www.geoplanning.tabrizu.ac.ir/article_809.html [Accessed 20 May 2020].

Karimpour Reihan M. and Sharif Jahed S. (2018). Strategic Management and Planning of Sustainable Tourism Development of Kerman Province with Emphasis on Tourism of Desert Shahdad. Geography (Regional Planning), 7(4), 7-18. [online] Available at: www.jgeogeshm.ir/ article_54095.html [Accessed 20 May 2020].

Kazemiyeh F., Sadighi H. and Chizari M. (2016). Investigation of Rural Tourism in East Azarbaijan Province of Iran Utilizing SWOT Model and Delphi Technique. Agricultural Science and Technology, 18(4), 911-923. [online] Available at: www.igtc12.modares.ac.ir/article-23-3436en.html [Accessed 20 May 2020].

Khatoonabadi A. and Rastghalam M. (2011). Measurement of the Four Dimensions of Rural Tourism, by SWOT Technique - Case Study: Target Tourism Rural of Chahar Mahal and Bakhtiari Province. Agricultural Economics and Development, 25(3), 330-338, DOI: 10.22067/jead2. v1390i3.10841.

Khougar F., Kiani M. and Kiani Dehkiani S. (2016). Assessment of Rural Rourism Potential and Facilities Using the SWOT Analysis (Case Study of Kolm Village). The First Scientific Conference on Civil, Architectural and Sustainable Environment. Tehran. [online] Available at: www. civilica.com/Paper-CACONF01-CACONF01_006.html [Accessed 20 May 2020].

Kim S. and Jamal T. (2015). The co-evolution of rural tourism and sustainable rural development in Hongdong, Korea: complexity, conflict and local response. Journal of Sustainable Tourism, 23(8-9), 1363-1385, DOI: 10.1080/09669582.2015.1022181.

Lane B. (1994). What is rural tourism? Journal of Sustainable Tourism, 2(1-2), 7-21, DOI: 10.1080/09669589409510680.

Lane B. (1994). Sustainable rural tourism strategies: A tool for development and conservation. Journal of Sustainable Tourism, 2(1-2), 102-111, DOI: 10.1080/09669589409510687...

Lv Z. (2019). Deepening or lessening? The effects of tourism on regional inequality. Tourism Management, 72, 23-26, DOl: 10.1016/j. tourman.2018.11.009

Mehrabi Boshrabadi H., Jalayi Esfandabadi S., Shakibaei A., and Javdan E. (2011). Investing the role of tourism in the economy of Kerman province and skeletal development of its regional cities. Urban Management, 9, 139-151. Retrieved from www.sid.ir/fa/journal/ViewPaper. aspx?id=165455

Mosavi M., Aftab A., Majnoni A. and Niromand S. (2019). Development of Rural areas Tourism with emphasis on priorities for investment in infrastructure (case study: Eastern Azarbaijan Province). Geographical Planning of Space Quarterly Journal, 9(31), 35-54, DOI: 10.30488/ gps.2019.90105.

Najmi S., Sharafi H. and Sabahi Garaghani Y. (2018). An Analysis of Urban Touristic Monuments Using the SWOT Technique; Case Study: Kerman City. Journal of The Iranian Studies, 16(32), 181-199. [online] Available at: www.jis.uk.ac.ir/article_1990.html [Accessed 20 May 2020].

Ommani A.R. (2011). Strategies of Rural Development in Shoushtar Township of Iran (Applying SWOT method). Journal of American Science, 7(1), 969-972. [online] Available at: www.scholar.google.com/scholar?oi=bibs\&cluster=3468260377897617341\&btnl=1\&hl=en [Accessed 20 May 2020].

Paresishvili O., Kvaratskhelia L. and Mirzaeva V. (2017). Rural tourism as a promising trend of small business in Georgia: Topicality, capabilities, peculiarities. Annals of Agrarian Science, 15(3), 344-348, DOI: 10.1016/j.aasci.2017.07.008.

Presidential Office of Iran (2015). Rural Development Document. Tehran: Kousha. 
Price G. and Murphy P. (2000). The relationship between ecotourism and sustainable development: A critical examination. Peak Performance in Tourism and Hospitality Research; Proceedings of the Tenth Australian Tourism and Hospitality Research Conference. La Trobe University, 189-202.

Ramezannezhad Y. and Roknoddin Eftekhari A. (2019). Strategies of Rural Costal Tourism Development of Guilan Province. Studies of Human Settlements Planning, 14(1), 19-34. [online] Available at: www.jshsp.iaurasht.ac.ir/article_665120.html [Accessed 20 May 2020].

Rasekhi S. and Mohammadi S. (2015). The Relationship between Tourism and Environmental Performance: The Case of Caspian Sea Nations. Iranian Journal of Economic Studies, 4(2), 51-80, DOI: 10.22099/ijes.2015.4122.

Rehak D. and Grasseova M. (2011). The Ways of Assessing the Security of Organization Information Systems Through SWOT Analysis. In M. Alshawi, \& M. Arif, Cases on E-Readiness and Information Systems Management in Organizations: Tools for Maximizing Strategic Alignment (1 ed., 162-184). IGI Global. [online] Available at: www.scholar.google.com/scholar?oi=bibs\&cluster=5911664666597088202\&btnl=1\&hl=th [Accessed 20 May 2020].

Reihanian A., Mahmood N.Z., Kahrom E. and Hin T.W. (2012). Sustainable tourism development strategy by SWOT analysis: Boujagh National Park, Iran. Tourism Management Perspectives, 4, 223-228, DOI: 10.1016/j.tmp.2012.08.005.

Riahy V. and Roshanali M. (2019). Investigating the Role of Tourism in the Development of Entrepreneurship in Rural Areas (Case study: Gharib Mahallah Village). Geographical Journal of Tourism Space, 8(30), 83-98. [online] Available at: www.gjts.malayeriau.ac.ir/article_665815. html [Accessed 20 May 2020].

Rid W., Ezeuduji I.O. and Pröbstl-Haider U. (2014). Segmentation by motivation for rural tourism activities in The Gambia. Tourism Management, 40, 102-116, DOI: 10.1016/j.tourman.2013.05.006.

Rivera J.R. and Gutierrez E.M. (2019). A framework toward sustainable ecotourism value chain in the Philippines. Journal of Quality Assurance in Hospitality \& Tourism, 20(2), 123-142, DOI: 10.1080/1528008X.2018.1492495.

Roknoddin Eftekhari A. and Ghaderi E. (2002). The Role of Rural Tourism in Rural Development (Theoretical Analysis). Journal of Spatial Planning, 6(2), 23-41. [online] Available at: www.journals.modares.ac.ir/article-21-4582-fa.html [Accessed 20 May 2020].

Salehpour S., Riahy V., Azizi A. and Fathizade F. (2019). The Feasibility of rural tourism development with an emphasis on sustainable development approach. Studies of Human Settlements Planning, 14(1), 111-127. [online] Available at:www.jshsp.iaurasht.ac.ir/article_665125. html [Accessed 20 May 2020].

Shafaei F., Mola F. and Mohamed B. (2015). Impact of Historical-Cultural Tourism on Sustaining Community Tourism: The Case of Kerman, Iran. Asian Social Science, 11(15), DOl: 10.5539/ass.v11n15p187.

Shi X. (2016). The future of ASEAN energy mix: A SWOT analysis. Renewable and Sustainable Energy Reviews, 53, 672-680, DOI: 10.1016/j. rser.2015.09.010.

Slee B., Farr H. and Snowdon P. (1997). The Economic Impact of Alternative Types of Rural Tourism. Journal of Agricultural Economics, 48(1-3), 179-192, DOI: 10.1111/j.1477-9552.1997.tb01144.x.

Sörensson A. (2014). Can Tourism Be Sustainable? Service Experiences from Tourism Destinations in Europe. Turku: School of Business and Economics, Åbo Akademi University.

Statistical Centre of Iran (2016). Population and Housing Census.

Statistical Centre of Iran (2019). Country Divisions.

Su B. (2011). Rural tourism in China. Tourism Management, 32(6), 1438-1441, DOI: 10.1016/j.tourman.2010.12.005.

Su M.M., Wall G. and Ma Z. (2014). Assessing Ecotourism from a Multi-stakeholder Perspective: Xingkai Lake National Nature Reserve, China. Environmental Management, 54(5), 1190-1207, DOI: 10.1007/s00267-014-0360-5.

Taboli H. and Yadollahi M. (2011). Tourism development strategies for Meymand village of Kerman, Iran (by SWOT model). The Journal of American Science, 7(3), 59-73, DOI: 10.7537/marsjas070311.08.

Tavallai S. (2006). Globalization as a Means for Tourism Development in Iran (Kerman). Geographical Researches, 21(3). [online] Available at: www.sid.ir/en/journal/ViewPaper.aspx?ID=57460 [Accessed 20 May 2020].

World Tourism Organization (UNWTO) (2015). Tourism and the Sustainable Development Goals, DOI: 10.18111/9789284417254.

Young Journalist Club (2016, September 5th). September, Peak of Beauty in Kiskan Village. [online] Available at: www.yjc.ir/000C0q [Accessed 20 May 2020].

Zare S., Hasheminezhad N., Sarebanzadeh K., Zolala F., Hemmatjo R. and Hassanvand D. (2018). Assessing thermal comfort in tourist attractions through objective and subjective procedures based on ISO 7730 standard: A field study. Urban Climate, 26, 1-9, DOI: 10.1016/j. uclim.2018.08.001.

Zhang X. (2012). Research on the Development Strategies of Rural Tourism in Suzhou Based on SWOT Analysis. International Conference on Future Energy, Environment, and Materials, 16, 1295-1299. Energy Procedia, DOI: 10.1016/j.egypro.2012.01.207. 